\title{
APPLICATION OF GIS FOR THE DESIGN OF POTABLE WATER DISTRIBUTION SYSTEM IN IIRS
}

\author{
Vaibhav Shrivastava ${ }^{1,}$ *, Akshay Jaiswal ${ }^{2}$, Praveen K. Thakur ${ }^{1}$, S. P Agarwal ${ }^{1}$, Pramod Kumar ${ }^{2}$, Ganesh Kumar Kota $^{2}$, \\ Dario Carrera ${ }^{2}$, Manish Kumar Dhasmana ${ }^{1}$, Vishal Sharma ${ }^{1}$, Sachchidanand Singh $^{1}$ \\ ${ }^{1}$ Water Resources Department, Indian Institute of Remote Sensing, Dehradun, India - vaibhav.iirs@ outlook.com; \\ (praveen, spa)@iirs.gov.in; (manishdhasmana49, vishal.iirs, sachin.iirs)@gmail.com \\ ${ }^{2}$ Indian Institute of Remote Sensing, Dehradun, India - jaiswal.akshay@ gmail.com \\ (pramod, ganeshkumar)@iirs.gov.in
}

Commission V, WG V/7

KEY WORDS: Potable water distribution, EPANET 2.0, Dehradun, Network analysis, pipeline

\begin{abstract}
:
The design and analysis of potable water distribution pipe network is one of the major task while planning any new city. Even finding the effectiveness and detecting any anomaly in the existing pipe line network is a very important to cut down losses and make a network all time efficient. This study makes an attempt to evaluate the existing water distribution network of Indian Institute of Remote Sensing (IIRS) and new pipe network to be developed under the master plan 2022. The new development induces an extra demand of 67634 litres per day (lpd). The Digital Globe image from Google Earth Pro is used for creating base layer and campus layout. ALOS PALSAR digital elevation model (DEM) is used to get elevation of nodes and tanks, which helps in alignment of pipes. Field survey was done for finding all the data necessary to make the database for input for EPANET 2.0. EPANET 2.0 pipe hydraulic model was used to test and design the existing and proposed potable water distribution pipe network. The results of evaluation of current operations show that the system can be made capable to fulfil the demand by increasing pumping time. But the future network operation requires an increase in pumping capability of 71 litre per minute (lpm) for filling Overhead tank. This study proves that geospatial technology is an efficient, time and cost saving alternative to the traditional methods of design and evaluation of potable water distribution networks.
\end{abstract}

\section{INTRODUCTION}

Geospatial technology has enabled us to create and use high resolution ortho-rectified images in conjunction with geographic information system (GIS) for spatial problems such as watershed characterization and sustainability, digital elevation models and natural and urban information systems (Khadri \& Pande, 2014). The GIS and remote sensing together with pipe hydraulic models has been effectively used for design and evaluation of water distribution networks. Developing countries face drawbacks of intermittent water supply system and are unable to shift to continuous supply mode (Mohapatra, Sargaonkar, \& Labhasetwar, 2014). In developing countries, urban water supplies, typically ranging from $2-4 \mathrm{~h}$ in a day (Ingeduld, Pradhan, Svitak, \& Terrai, 2006). In India, water supply rate varies from 16 to 3001 per capita per day (lpcd) depending on the locality and the economic status (Singh \& Turkiya, 2013). This study makes an attempt to study the water distribution system of potable water using geospatial tools in near-real time scenario. The GIS framework for water distribution networks provides functions for development and preparation of accurate spatial information model, which includes network layout, pipe characteristics and cost, head loss, demand patterns, cost analysis, network routing and allocation and effective color graphic display of results (Venkata Ramana \& Sudheer Chekka, 2018). The water distribution systems typically have two important aspects: (1) to serve the water demand for the community and (2) to provide sufficient water for firefighting (Farina, Creaco, \& Franchini, 2014). A properly installed water distribution system with adequate fire flow typically lasts for 70 to 100 years (Bahadori, 2016). GIS can be used as a long term planning and management tool as it can be easily updated as development occurs. The hydraulic simulation models like EPANET 2.0,
WaterGems, KY Pipe etc. are key tools for design, analysis, operation and maintenance of the water distribution systems (Berardi, Laucelli, Ridolfi, \& Giustolisi, 2014; Kanakoudis \& Gonelas, 2014; Koor, Puust, \& Vassiljev, 2014). These models are capable of tracking flows in each pipe, pressure at each node and concentration of chemicals throughout the pipe network during a simulation period (Rajeswaran, Narasimhan, \& Narasimhan, 2018).

The main research objective of this work is to assess the geospatial techniques for the design and evaluation of potable water distribution network in the campus of Indian Institute of Remote Sensing (IIRS). To check if the existing network running efficiently and will be able to run efficiently even after the increasing the demand according to the master plan 2022.

\section{STUDY AREA}

The campus of Indian Institute of Remote Sensing (IIRS) Dehradun is the study area for this work (Figure 1). IIRS campus is located in 4-Kalidas Road, Dehradun, and is divided in two parcels; a parcel to the north of the road, containing the main IIRS buildings, and second one is to the south of the Kalidas Road, where only houses of the employees of the IIRS are located (Figure 4). The inside campus includes a land area of approximately $\sim 9$ ha, whereas the land from the colony to the South of the Kalidas road has an approximate area of 0.95 ha, with total area of $\sim 10$ ha. Campus is located between coordinates $78^{\circ} 02^{\prime} 35.44^{\prime \prime} \mathrm{E}$ and $30^{\circ} 20^{\prime} 29.17^{\prime \prime} \mathrm{N}$ to $78^{\circ} 03^{\prime} 01.45^{\prime \prime}$ $\mathrm{N}$ and $30^{\circ} 20^{\prime} 15.73 "$ E. The existing network (Figure 2) has to supply water at maximum rate up to $297.64 \mathrm{lpm}$ which may increase to $\mathbf{3 4 6 . 8 7} \mathrm{lpm}$ for future network (Figure 3). As the new development induces an extra demand of 67634 litres per day (lpd).

\footnotetext{
${ }^{*}$ Corresponding author
} 


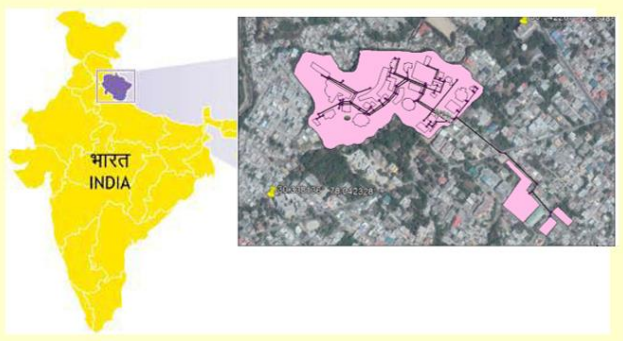

Figure 1. Study area IIRS campus and colony

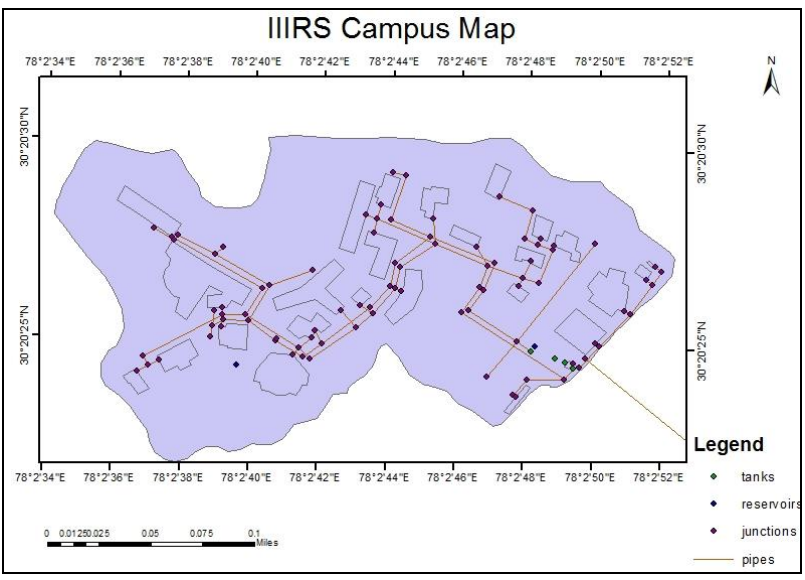

Figure 2. Existing pipe network

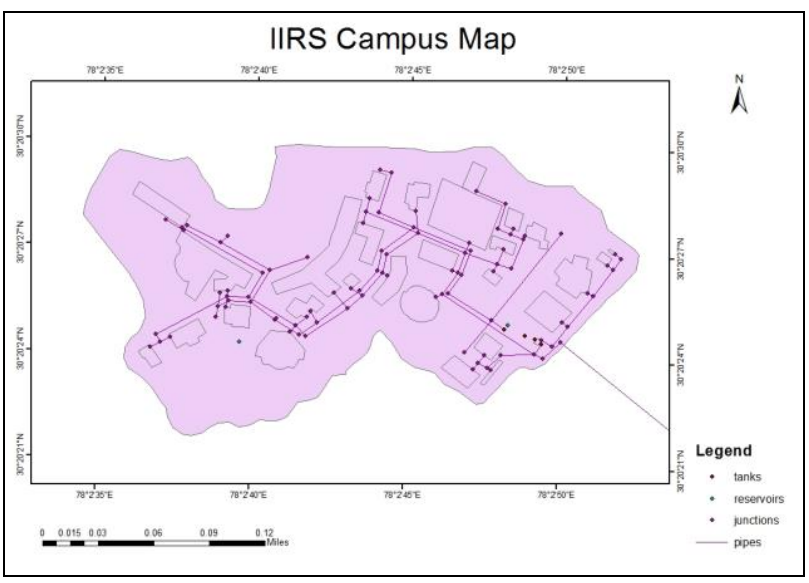

Figure 3. Future pipe network

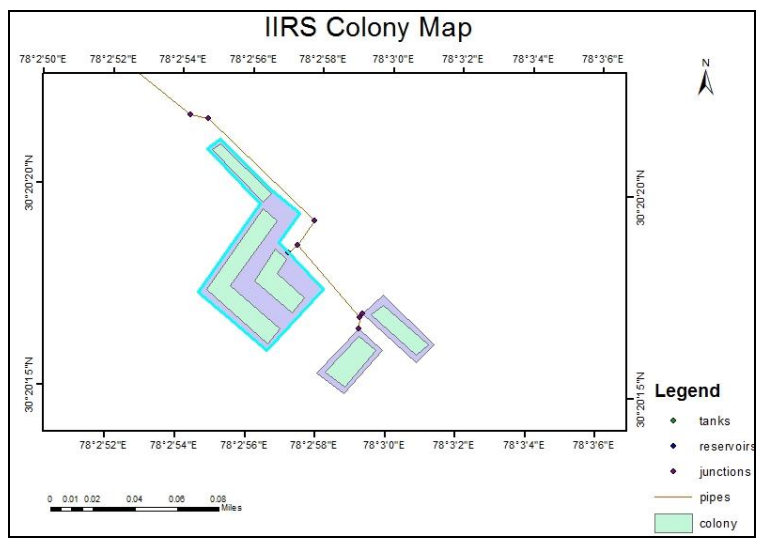

Figure 4. Colony of IIRS employees

\section{METHODOLOGY}

In this project the hydraulic model of EPANET 2.0 was used to analyse the nodes pressures and create the system of the water distribution network. For which shape file and INP file was made using GHydraulics plugin in QGIS. Topology was checked in ArcGIS 10.1. Running EPANET 2.0 for water distribution network analysis for the maximum demand and running both the network for 24 hours simulation results are generated.

The data used in this work is as follows: The high resolution image of the southwest of Dehradun (Digital Globe Imagery taken from Google Earth). Map plan of the IIRS with the potable water pipe network is taken from Construction and Maintained Department (CMD) of IIRS, Digital Elevation Model (DEM) of the evaluated area (Alos Palsar $12.5 \mathrm{~m}$ ), population data of the IIRS campus, pipe diameters and material, location, height and volume of water tanks, specification of pumping and tube-wells, time of operation of wells (from field survey and CMD data).

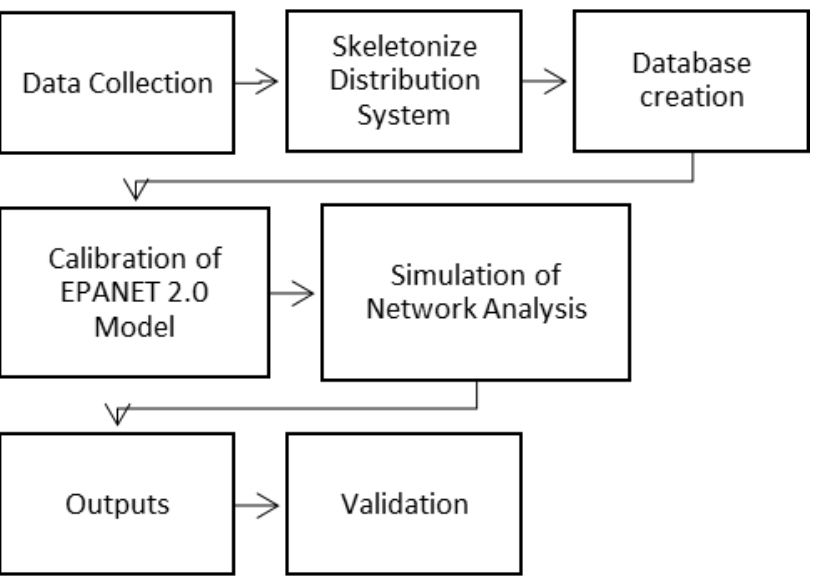

Figure 5. Methodology flow chart

\section{HYDRAULIC PARAMETERS \& GEOSPATAII DATA}

The principal hydraulic input parameters for pipes in this work are:

- Start and end nodes

- Diameter

- Length

- Roughness coefficient (for determining head-loss)

- Status (open, closed, or contains a check valve).

The status parameters allows pipes to implicitly contain shutoff (gate) valves and Check (non-return) valves (which allow flow in only one direction). Computed outputs for pipes include:

- Demand

- Velocity

- Head-loss

- Pressure

The hydraulic head lost by water flowing in the network due to friction with the pipe walls are computed using HazenWilliams formula (Brandt, Johnson, Elphinston, \& Ratnayaka, 2017). The Hazen-Williams formula is the most commonly used head-loss formula for pipe flow in the world (Sanks et al., 
2008). It cannot be used for liquids other than water and was originally developed for turbulent flow only (McAllister, 2014b, 2014a). Hazen-Williams formula uses the following equations to compute head-loss between the start and end node of the pipe:

$$
h_{L}=A * q^{B}
$$

Where:

$$
\begin{aligned}
& \mathrm{h}_{\mathrm{L}}=\text { head-loss (Length) } \\
& \mathrm{q}=\text { flow rate (Volume/Time) } \\
& \mathrm{A}=\text { resistance Coefficient } \\
& \mathrm{B}=\text { flow exponent }(1.852) .
\end{aligned}
$$

The resistance coefficient Hazen-Williams formula is:

$$
A=10.7 C^{-1.852} d^{-4.871}
$$

$$
\text { Where: } \quad \begin{aligned}
& \mathrm{C}=\text { Hazen-Williams roughness coefficient } \\
& \mathrm{d}=\text { inside pipe diameter }
\end{aligned}
$$

\subsection{Geospatial Data}

The Digital Globe Imagery taken from Google Earth Pro orthorectified images is used for creation of all required GIS data layers.

The water distribution pipe network of campus area is taken from Construction and Maintenance Division (CMD) of IIRS All images and maps were re-projected in UNIVERSAL Transverse Mercator (UTM), Spheroid: WGS 84, Datum: WGS 84, UTM Zone 44 North. The buildings located within the IIRS Campus (Figure 2,3) are digitised. DEM in a grid format is used for extracting the elevation values of each node of the pipe network in ArcGIS 10.1.

\section{NETWORK PERAMETERS}

The population data used to consider the demand of potable water was provided by the CMD of the IIRS. The potable water distribution pipe networks of IIRS, was exported for its hydraulic simulation in EPANET 2.0. For the hydraulic simulation in this software it is necessary to provide the following information of nodes, pipes, tanks, pumps and storage reservoirs:

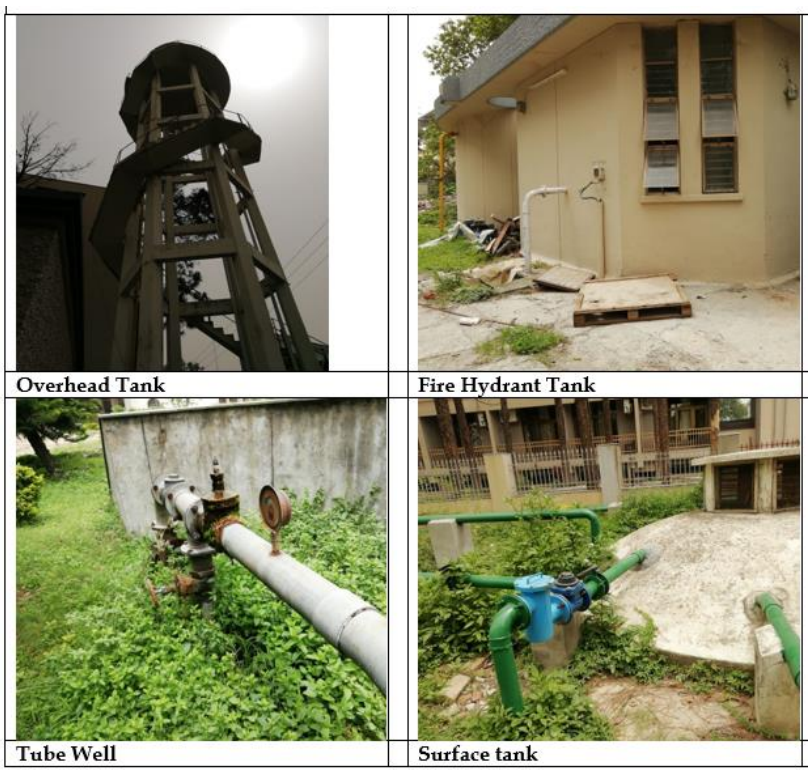

Figure 6 Field Data collection

\subsection{Nodes}

The data required for each node in the simulation of the potable water distribution network is:

5.1.1 Node ID: This parameter is given automatically by the program; you need to go to the main window Project/Defaults and to place the nomenclature that is desired for each element in the network (node, pipe, tank, pump, valves).

5.1.2 Coordinates of the node: For each node requires the coordinate so that among them latitude/longitude of each section of pipe can be considered, this parameter is automatically taken as the pipe network were drawn and created with geo-coded base image.

5.1.3 Demand in the node: Once design population is obtained for the IIRS, the potable water demand is estimated, using the same demand depending on the type of building. For this case it will be essential to include in the total demand, the demand generated by the future habitants of the IIRS is $\mathbf{3 4 6 . 8 7}$ lpm, which is a considerable change and will effect present distribution pattern.

5.1.4 Elevation: For this parameter Garmin GPS equipment was used to know the elevation in the different points of the IIRS, and this data and DEM is used in the simulation.

5.1.5 Demand pattern: The previously calculated demand is the maximum water request in the area, throughout the day this demand is not more than the $100 \%$. For the simulation of the network in the Institute a pattern was selected for maximum of demand per hour to know the average consumed water of the day, which for this area works out to be $60 \%$. The pattern assigned to the evaluated networks.

\subsection{Pipes}

The data required for in each pipe for the simulation of the water distribution network is:

5.2.1 Pipe ID: This parameter is given automatically by the program; you need to go to the main window project and to place the nomenclature that is desired for each pipe in the network.

5.2.2 Length: This parameter is calculated automatically in ArcGIS 3.3 when it is having the coordinates of each node, than it is easy to obtain the length between each one of these elements. For this simulation length is expressed in meters.

5.2.3 Diameter: In this parameter introduces the diameter to each section of pipe. For this work the diameters were used as given in the plan facilitated by the CMD of the IIRS; these pipes go from the 80 millimetres to the 100 millimetres.

5.2.4 Roughness of the pipe: In this parameter roughness is introduced by value established for the material selected for the pipes that formed the potable water distribution network. In the case of this network, as per CMD of the IIRS, existing pipes are of Galvanized Iron, which gives roughness value of 120 .

\subsection{Tanks}

The data required for each tank in the simulation of the potable water distribution network is: 
5.3.1 Tanks ID: This parameter is given automatically by the program; you need to go to the main window project/defaults and to place the nomenclature that is desired for each tank in the network.

5.3.2 Elevation: This parameter unlike the elevation in the nodes is placed manually in EPANET 2.0, because it is needed to include the elevation of the tank and along with the elevation in the land (Table 1).

\begin{tabular}{|c|c|c|c|}
\hline Tanks & $\begin{array}{c}\text { ELEVATION } \\
\text { OF THE } \\
\text { GROUND OF } \\
\text { TANKS } \\
\text { (MSL) }\end{array}$ & $\begin{array}{c}\text { HEIGHT } \\
\text { OF THE } \\
\text { TANKS }\end{array}$ & $\begin{array}{c}\text { TOTAL } \\
\text { ELEVATION } \\
\text { OF THE } \\
\text { TANK }\end{array}$ \\
\hline $\begin{array}{c}\text { Tank 1 } \\
\text { (OHT) }\end{array}$ & 667 & 20 & 688 \\
\hline Tank 2 & 667 & 4 & 671 \\
\hline Tank 3 & 667 & 4 & 671 \\
\hline $\begin{array}{c}\text { Tank 4 } \\
\text { (FHT) }\end{array}$ & 667 & 5.05 & 672.05 \\
\hline
\end{tabular}

OHT: Over Head Tank

FHT: Fire Hydrant Tank

Table 1 Tank Height

\begin{tabular}{|c|c|c|c|c|}
\hline TANKS & $\begin{array}{c}\text { WIDE } \\
(\mathbf{m})\end{array}$ & $\begin{array}{c}\text { HEIGHT } \\
(\mathbf{m})\end{array}$ & $\begin{array}{c}\text { LENGTH } \\
(\mathbf{m})\end{array}$ & $\begin{array}{c}\text { VOLUME } \\
\left(\mathbf{M}^{\mathbf{3}}\right)\end{array}$ \\
\hline $\begin{array}{c}\text { TANK } \\
2\end{array}$ & 4 & 3.13 & 4 & 50 \\
\hline $\begin{array}{c}\text { TANK } \\
3\end{array}$ & 5 & 4 & 5 & 100 \\
\hline
\end{tabular}

Table 2 Tanks Dimensions

5.3.3 Initial level, minimum level, maximum level and diameter: In order to obtain these four (4) parameters one had to consider the dimensions of each tanks; in the case of the IIRS three (3) main tanks exist, one (1) of 100,000 1 and two (2) of combined capacity of 50,000 1 which during skeletonization of network is combined to make one tank of 150,0001 . Two of these existing tanks have rectangular form and their approximate dimensions are given in the table 2. However the data required in EPANET 2.0 for the details of tanks, still works under the cylindroids tank option, which forces us to consider maximum new dimensions as function of the volume, which appear are given in table 3 .

\subsection{Pumps}

The data required in each pump for the simulation of the potable water distribution network is:

5.4.1 Pump ID: This parameter is given automatically by the program; you need to go to the main window project/defaults and to place the nomenclature that is desired for each pump element in the network.
5.4.2 Pump Curve: With the help of the CMD of the IIRS, it was possible to know the diameters of the pumping pipes, the level of pumping and the elevation of pumping. With this information the parameters (Flow and Head) were calculated for further simulation in EPANET 2.0. (Table 4) shows the present specifications of each pump.

5.4.3 Pattern: The time of daily pumping is known for each pump, which is given in the table 5 .

\begin{tabular}{|c|c|c|c|c|}
\hline TANKS & $\begin{array}{c}\text { CAPACITY } \\
(\mathbf{L})\end{array}$ & $\begin{array}{c}\text { DIAMETER } \\
(\mathbf{m})\end{array}$ & $\begin{array}{c}\text { HEIGHT } \\
(\mathbf{m})\end{array}$ & $\begin{array}{c}\text { VOLUME } \\
(\mathbf{M 3})\end{array}$ \\
\hline OHT & $50,000.00$ & 4 & 4 & 50 \\
\hline UT1 & $150,000.00$ & 6.88 & 4 & 150 \\
\hline Tank 3 & $100,000.00$ & 5.05 & 4 & 100 \\
\hline
\end{tabular}

UT1: United Tank 1 (Tank 2 + Tank 3)

Table 3 Tanks capacity

\begin{tabular}{|c|c|c|}
\hline ELEMENT & HEAD (M) & FLOW (LPM) \\
\hline PUMP1 & 150.00 & 450.00 \\
\hline PUMP2 & 150.00 & 450.00 \\
\hline PUMP3 & 20.00 & 200.00 \\
\hline PUMP4 & 20.00 & 200.00 \\
\hline PUMP5 & 20.00 & 250.00 \\
\hline PUMP6 & 20.00 & 150.00 \\
\hline
\end{tabular}

Table 4 Pump specification

\begin{tabular}{|c|c|c|c|}
\hline PUMPS & \multicolumn{3}{|c|}{ Time } \\
\hline PUMP 1 & $\begin{array}{c}5 \text { am to } 10 \\
\text { am }\end{array}$ & $\begin{array}{c}12 \mathrm{pm} \text { to } \\
2 \mathrm{pm}\end{array}$ & $\begin{array}{c}5 \mathrm{pm} \text { to } \\
9 \mathrm{pm}\end{array}$ \\
\hline PUMP 2 & $\begin{array}{c}5 \text { am to } 10 \\
\text { am }\end{array}$ & $\begin{array}{c}12 \mathrm{pm} \text { to } \\
2 \mathrm{pm}\end{array}$ & $\begin{array}{c}5 \mathrm{pm} \text { to } \\
9 \mathrm{pm}\end{array}$ \\
\hline PUMP 3 & $\begin{array}{c}5 \text { am to } 10 \\
\text { am }\end{array}$ & $\begin{array}{c}12 \mathrm{pm} \text { to } \\
2 \mathrm{pm}\end{array}$ & $\begin{array}{c}5 \mathrm{pm} \text { to } \\
9 \mathrm{pm}\end{array}$ \\
\hline PUMP 4 & $\begin{array}{c}5 \mathrm{am} \text { to } 10 \\
\text { am }\end{array}$ & $\begin{array}{c}12 \mathrm{pm} \text { to } \\
2 \mathrm{pm}\end{array}$ & $\begin{array}{c}5 \mathrm{pm} \text { to } \\
9 \mathrm{pm}\end{array}$ \\
\hline PUMP 5 & & $\begin{array}{c}12 \mathrm{pm} \text { to } 2 \\
\mathrm{pm}\end{array}$ & \\
& & $12 \mathrm{pm}$ to & \\
\hline PUMP 6 & 7 am to $9 \mathrm{am}$ & $\mathrm{pm}$ & \\
& & &
\end{tabular}

Table 5 Pumping timing

\subsection{Reservoir}

For this simulation parameter reservoir represented wells both that supply to the existing networks. The data required for each reservoir for the simulation of the potable water distribution network is (Table 6): 


\begin{tabular}{|c|c|c|c|}
\hline WELLS & $\begin{array}{c}\text { BOTTOM } \\
\text { OF WELL } \\
\text { (MSL) }\end{array}$ & $\begin{array}{c}\text { DEPTH } \\
\text { OF WELL } \\
(\mathbf{m})\end{array}$ & $\begin{array}{c}\text { TOTAL } \\
\text { HEAD (m) }\end{array}$ \\
\hline Well 1 & 651 & 99 & 552 \\
\hline Well 2 & 658 & 99 & 559 \\
\hline
\end{tabular}

Table 6 Tube well (Reservoir) specifications

5.5.1 Total Head: This parameter is the sum of the height of land where reservoir is located, and the piezometric or energy head that it had when coming out of well, in this case there are two wells. For this case the depth of pumping of each well could be obtained, which was reduced from ground level of the tanks to obtain the elevation of each wells with respect to the mean sea level. The Flow and Head each pump is considered from the formulas of pump Horse Power (HP). Knowing the pumping level of each well and the elevation of each tank, the minimum Head was obtained for the pumps; from this Head, Power formula is used to obtain the maximum volume of each pump. Evaluation is done to check that how much volume can be pumped through $80 \mathrm{~mm}$ diameter pipes which are used for feeding the tanks; which allows to calculate the three elements that form the equation of flow $\left(\mathrm{Q}=\mathrm{V}^{*} \mathrm{~A}\right)$, from two of them (Diameter, Velocity and Flow,). For a pipe of $80 \mathrm{~mm}$ maximum volume that can be pumped is $750 \mathrm{lpm}$.

\section{RESULT AND DISCUSSIONS}

Analysis of the existing network was done in EPANET 2.0 and it was successfully able to fulfil the demand till 5:00 pm (Figure 7) after which a negative pressure develops in the node of main building (J35 node of the network) (Table 7). That gets soon corrected as the pumping is restarted at $6 \mathrm{pm}$ (Figure 9). The network was also tested for worst possible case when there is a fire demand at 12:00 pm to 2:00 pm (Figure 10) which required increased pumping time. Hence the network can be corrected by increasing pumping time for filling the Overhead tank by one more hour from 2:00 pm to 3:00 pm.

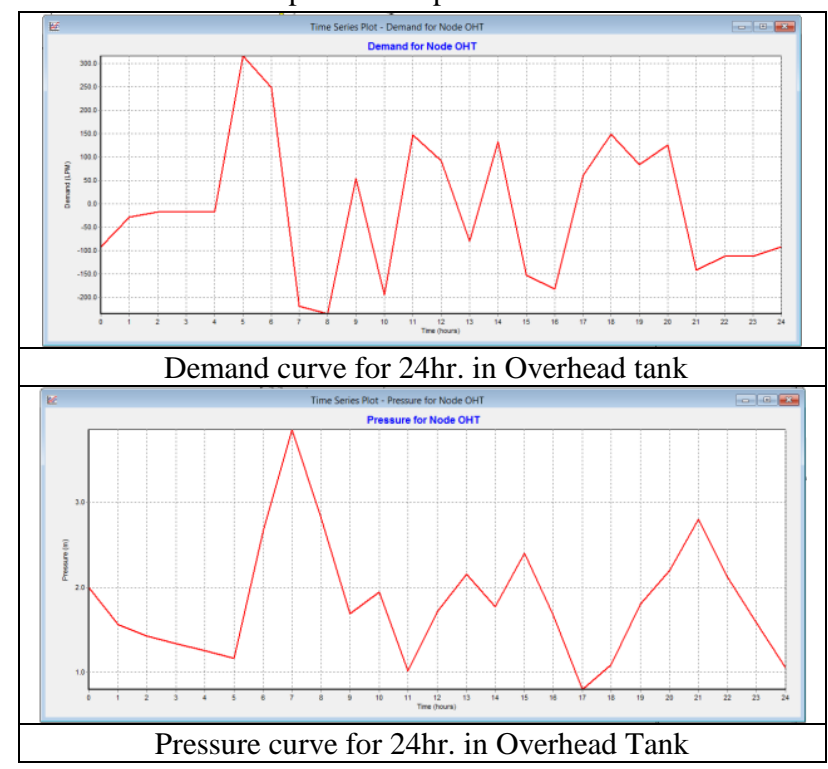

Figure 7 Curves generated by EPANET 2.0

While running the network at the same pumping pattern and capacity for the future network (according to the master plan 2022) there were problems in the network (Figure 8).

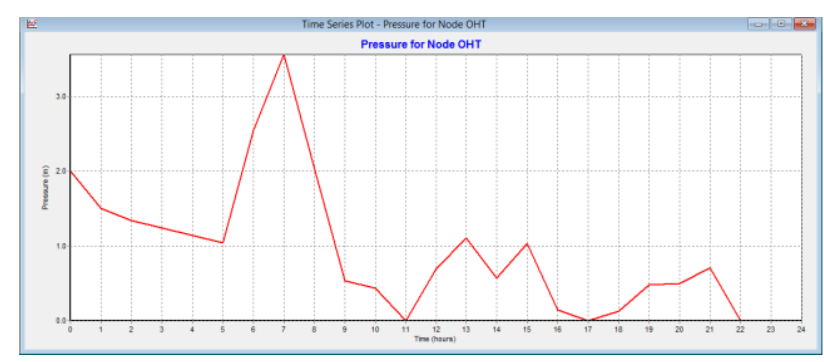

Figure 8 Pressure curve of overhead tank of unsuccessful run

As the overhead tank was unable to fill at the rate at which water was needed to be delivered. Which can be corrected by increasing the flow capacity of the pump that fills the overhead tank from the surface tanks. The network was able to run successfully when flow capacity was increased by 71 litre per minute.

\begin{tabular}{|c|c|c|c|}
\hline $\begin{array}{l}\text { Time } \\
\text { Hours }\end{array}$ & $\begin{array}{l}\text { Demand } \\
\text { LPM }\end{array}$ & $\begin{array}{c}\text { Head } \\
\text { m }\end{array}$ & $\begin{array}{c}\text { Pressure } \\
\mathrm{m}\end{array}$ \\
\hline $0: 00$ & 8.98 & 689.70 & 36.70 \\
\hline $1: 00$ & 1.80 & 689.53 & 36.53 \\
\hline $2: 00$ & 1.80 & 689.41 & 36.41 \\
\hline $3: 00$ & 1.80 & 689.32 & 36.32 \\
\hline $4: 00$ & 1.80 & 689.24 & 36.24 \\
\hline $5: 00$ & 1.80 & 689.15 & 36.15 \\
\hline $6: 00$ & 1.80 & 691.14 & 38.14 \\
\hline $7: 00$ & 53.91 & 684.70 & 31.70 \\
\hline $8: 00$ & 53.91 & 683.29 & 30.29 \\
\hline 9:00 & 26.95 & 688.36 & 35.36 \\
\hline $10: 00$ & 26.95 & 689.82 & 36.82 \\
\hline $11: 00$ & 26.95 & 688.90 & 35.90 \\
\hline $12: 00$ & 35.94 & 689.19 & 36.19 \\
\hline 13:00 & 53.91 & 686.50 & 33.50 \\
\hline $14: 00$ & 26.95 & 688.62 & 35.62 \\
\hline $15: 00$ & 17.97 & 688.31 & 35.31 \\
\hline $16: 00$ & 17.97 & 687.35 & 34.35 \\
\hline $17: 00$ & 17.97 & -5088335.00 & -5088988.00 \\
\hline 18:00 & 8.98 & 688.16 & 35.16 \\
\hline $19: 00$ & 8.98 & 689.01 & 36.01 \\
\hline $20: 00$ & 8.98 & 690.27 & 37.27 \\
\hline $21: 00$ & 8.98 & 691.44 & 38.44 \\
\hline $22: 00$ & 8.98 & 690.93 & 37.93 \\
\hline $23: 00$ & 8.98 & 690.39 & 37.39 \\
\hline $24: 00$ & 8.98 & 689.96 & 36.96 \\
\hline
\end{tabular}

Table 7 Demand, head and pressure variation at J35 node (main building).

The head and pressure becomes negative at 5pm (17:00 hours). This means that there is no water supply in the main building at $5 \mathrm{pm}$. 


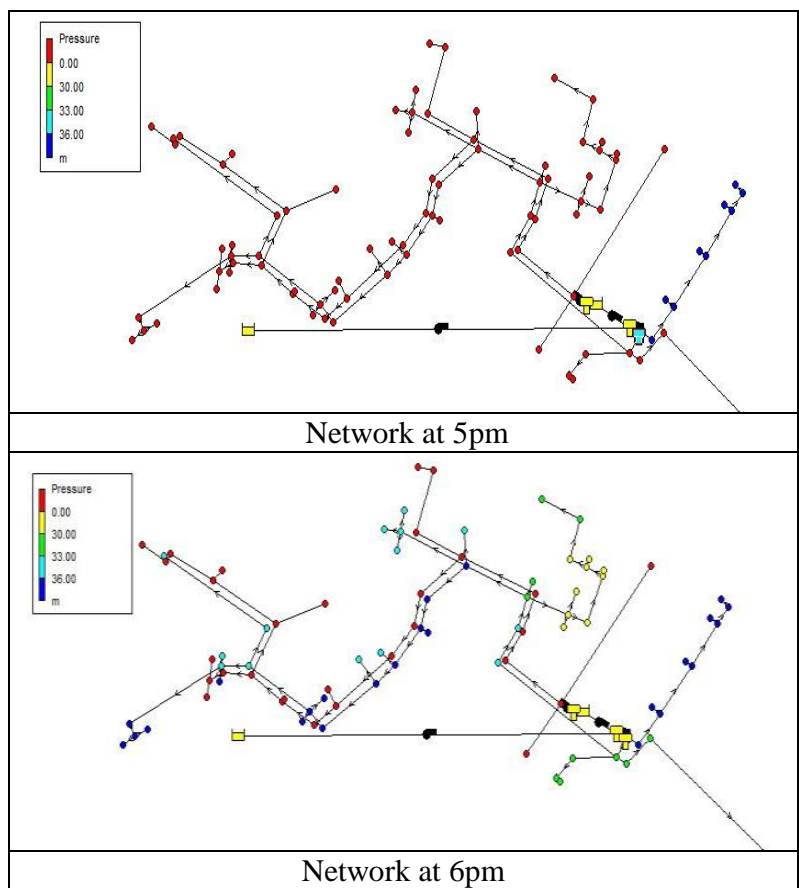

Figure 9 Network at $5 \mathrm{pm}$ shows negative pressure and gets corrected at $6 \mathrm{pm}$

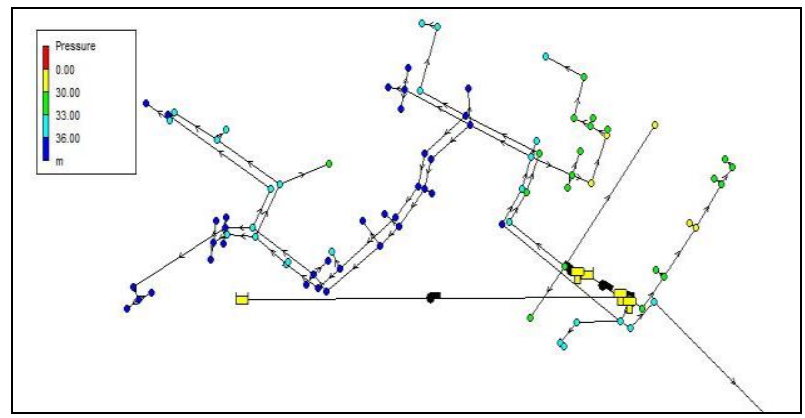

Figure 10 Network successfully satisfying fire demand at $12 \mathrm{pm}$

\section{CONCLUSION}

The present pumping can be corrected by increasing the pumping time for one more hour from 2:00 pm to $3: 00 \mathrm{pm}$. While future network would require pumping of $100 \mathrm{lpm}$ flow and $20 \mathrm{~m}$ head. This can be installed with the two pumps already running in parallel connection to fill the overhead tank from the surface tanks. As this will also satisfy the demand which will be created if fire broke out in the new proposed buildings. As these buildings will not be connected by existing fire hydrant network, hence the demand at the time of fire in these buildings has to be fulfilled by the potable water supply network.

The simulation can be further corrected by incorporating details of water tanks on each building which will make us analyse intermittent supply of water. As valves are not incorporated in this study the friction losses are not exactly calculated. Which may be further included in the model in future.

This study proves that geospatial technology is an efficient, time and cost saving alternative to the traditional methods of design and evaluation of potable water distribution networks. GIS technology is need of the hour for designing and evaluation of complex water distribution systems. This can help in decision making and planning of the networks, which are future ready, efficient and cost effective. EPANET 2.0 is a very handy tool that can be used by the engineers and planners to plan and check their existing and proposed water distribution network designs. Any problem in the design can be found beforehand and can be corrected by any number of iterations.

\section{REFERENCES}

Bahadori, A. (2016). Chapter 8 - Water supply and distribution systems. In A. Bahadori (Ed.), Essentials of Oil and Gas Utilities (pp. 225-328). Gulf Professional Publishing. https://doi.org/https://doi.org/10.1016/B978-0-12-8030882.00008-0

Berardi, L., Laucelli, D., Ridolfi, L., \& Giustolisi, O. (2014). WQNetXL: A MS-excel Water Quality System Tool for WDNs. Procedia Engineering, 89, 262-272. https://doi.org/https://doi.org/10.1016/j.proeng.2014.11.186

Brandt, M. J., Johnson, K. M., Elphinston, A. J., \& Ratnayaka, D. D. (2017). Chapter 14 - Hydraulics. In M. J. Brandt, K. M. Johnson, A. J. Elphinston, \& D. D. Ratnayaka (Eds.), Twort's Water Supply (Seventh Edition) (Seventh Ed, pp. 581-619). Boston: Butterworth-Heinemann. https://doi.org/https://doi.org/10.1016/B978-0-08-100025$0.00014-4$

Farina, G., Creaco, E., \& Franchini, M. (2014). Using EPANET for modelling water distribution systems with users along the pipes. Civil Engineering and Environmental Systems, 31(1), 36-50. https://doi.org/10.1080/10286608.2013.820279

Ingeduld, P., Pradhan, A., Svitak, Z., \& Terrai, A. (2006). Modelling Intermittent Water Supply Systems With EPANET. Water Distribution Systems Analysis Symposium 2006, (1), 3-4. https://doi.org/10.1061/40941(247)37

Institution[ISI], I. S. (1984). IS:1172-1983. Indian standard code of basic requirements for water supply drainage and sanitation. New Delhi: Indian Standards Institution.

Kanakoudis, V., \& Gonelas, K. (2014). Applying Pressure Management to Reduce Water Losses in Two Greek Cities' WDSs: Expectations, Problems, Results and Revisions. Procedia Engineering, 89, 318-325. https://doi.org/https://doi.org/10.1016/j.proeng.2014.11.194

Khadri, S., \& Pande, C. (2014). Water Supply Systems-A Case Study On Water Network Distribution in Chalisgaon City in Dhule District Maharashtra Using Remote Sensing \& GIS Techniques. Iosrjournals.Org, 2014, 1-12. Retrieved from http://iosrjournals.org/iosr-jmce/papers/ICAET-

2014/ce/volume-4/1.pdf

Koor, M., Puust, R., \& Vassiljev, A. (2014). Database Driven Updatable Hydraulic Model for Decision Making. Procedia Engineering, 70, 959-968. https://doi.org/10.1016/J.PROENG.2014.02.107 
McAllister, E. W. (Ed.). (2014a). 13 - Liquids-Hydraulics. In Pipeline Rules of Thumb Handbook (Eighth Edition) (Eighth Edition, pp. 413-469). Boston: Gulf Professional Publishing. https://doi.org/https://doi.org/10.1016/B978-0-12-3876935.00013-9

McAllister, E. W. (Ed.). (2014b). 3 - Pipe Design. In Pipeline Rules of Thumb Handbook (Eighth Edition) (Eighth Edition, pp. 93-123). Boston: Gulf Professional Publishing. https://doi.org/https://doi.org/10.1016/B978-0-12-3876935.00003-6

Mohapatra, S., Sargaonkar, A., \& Labhasetwar, P. K. (2014). Distribution network assessment using EPANET for intermittent and continuous water supply. Water Resources Management, 28(11), 3745-3759. https://doi.org/10.1007/s11269-014-0707-y

Rajeswaran, A., Narasimhan, S., \& Narasimhan, S. (2018). A graph partitioning algorithm for leak detection in water distribution networks. Computers \& Chemical Engineering, 108 , $11-23$. https://doi.org/https://doi.org/10.1016/j.compchemeng.2017.08. 007

Sanks, R. L., Amirtharajah, A., Cahoon, J. E., Cunningham, A. B., Gros, W. F. H., Hecker, G. E., ... Wheeler, W. (2008). Chapter 3 - Flow in Conduits. In G. M. Jones, R. L. Sanks, G. Tchobanoglous, \& B. E. Bosserman (Eds.), Pumping Station Design (Third Edition) (Third Edit, p. 3.1-3.37). Burlington: Butterworth-Heinemann.

https://doi.org/https://doi.org/10.1016/B978-1856175135.50010-X

Singh, O., \& Turkiya, S. (2013). A survey of household domestic water consumption patterns in rural semi-arid village, India. GeoJournal, 78(5), 777-790. https://doi.org/10.1007/s10708-012-9465-7

Venkata Ramana, G., \& Sudheer Chekka, V. S. S. (2018). Validation and Examination of Existing Water Distribution Network for Continuous Supply of Water Using EPANET. Water Resources Management, 32(6), 1993-2011. https://doi.org/10.1007/s11269-017-1889-x

\section{APPENDIX}

(a) Existing Water Demand Chart

\begin{tabular}{|c|c|c|c|}
\hline NAME & POPULATION & $\begin{array}{c}\text { DEMAND } \\
\text { PER } \\
\text { CAPITA } \\
\text { (lpcd) }\end{array}$ & $\begin{array}{c}\text { DEMAND } \\
(\mathrm{lpm})\end{array}$ \\
\hline $\begin{array}{c}\text { House Blocks: } \\
\text { D1-D4(10P) }\end{array}$ & 40 & 200 & 6.39 \\
\hline $\begin{array}{c}\text { House Blocks: } \\
\text { C5-C8(8P) }\end{array}$ & 32 & 175 & 4.47 \\
\hline $\begin{array}{c}\text { House Blocks: } \\
\text { E3-E4 }\end{array}$ & 14 & 200 & 2.24 \\
\hline $\begin{array}{c}\text { House Blocks: } \\
\text { E2 }\end{array}$ & 10 & 200 & 1.60 \\
\hline
\end{tabular}

\begin{tabular}{|c|c|c|c|}
\hline $\begin{array}{l}\text { SECURITY } \\
\text { OFFICE }\end{array}$ & 7 & 45 & 0.25 \\
\hline $\begin{array}{c}\text { House Blocks: } \\
\text { E1 }\end{array}$ & 10 & 200 & 1.60 \\
\hline LIBRARY & 50 & 45 & 1.80 \\
\hline CANTEEN & 300 & 70 & 16.77 \\
\hline BLOCK C & 30 & 135 & 3.23 \\
\hline $\begin{array}{l}\text { CSSTEAP } \\
\text { HOSTEL }\end{array}$ & 100 & 135 & 10.78 \\
\hline BLOCK B & 60 & 135 & 6.47 \\
\hline CSSTEAP & 60 & 70 & 3.35 \\
\hline $\begin{array}{c}\text { MAIN } \\
\text { BUILDING }\end{array}$ & 500 & 45 & 17.97 \\
\hline STORE & 10 & 45 & 0.36 \\
\hline GID & 150 & 45 & 5.39 \\
\hline URSD & 300 & 45 & 10.78 \\
\hline $\begin{array}{l}\text { House Blocks: } \\
\text { B1 - B6(6P) }\end{array}$ & 36 & 135 & 3.88 \\
\hline $\begin{array}{l}\text { GOLDEN } \\
\text { JUBILEE }\end{array}$ & 300 & 135 & 28.2 \\
\hline $\begin{array}{l}\text { GUEST } \\
\text { HOUSE }\end{array}$ & 50 & 135 & 5.39 \\
\hline DISPENSARY & 10 & 45 & 0.36 \\
\hline FOUNTAIN & & & 0.70 \\
\hline Block E & 200 & 135 & 21.56 \\
\hline GYM & 50 & 45 & 1.79 \\
\hline ADMIN & 120 & 45 & 4.31 \\
\hline \multirow[t]{4}{*}{ Block A } & 200 & 70 & \\
\hline & 130 & 70 & \\
\hline & 84 & 135 & \\
\hline & & Total & 27.55 \\
\hline \multirow[t]{4}{*}{ Iirs Colony 1} & 126 & 200 & \\
\hline & 40 & 135 & \\
\hline & 16 & 135 & \\
\hline & & & 27.25 \\
\hline Iirs Colony 2 & 28 & 200 & 5.47 \\
\hline \multirow[t]{2}{*}{ Iirs Colony 3} & 28 & 200 & 5.47 \\
\hline & & & 297.64 lpm \\
\hline
\end{tabular}

\section{(b) Future Water Demand Chart}

\begin{tabular}{|c|c|c|c|}
\hline NAME & POPULATION & $\begin{array}{c}\text { DEMAND } \\
\text { PER } \\
\text { CAPITA } \\
\text { (lpcd) }\end{array}$ & $\begin{array}{c}\text { DEMAND } \\
(\mathrm{lpm})\end{array}$ \\
\hline PARK & 50 & 45 & 1.80 \\
\hline $\begin{array}{c}\text { House Blocks: } \\
\text { D1-D4(10P) }\end{array}$ & 40 & 200 & 6.39 \\
\hline
\end{tabular}


ISPRS Annals of the Photogrammetry, Remote Sensing and Spatial Information Sciences, Volume IV-5, 2018 ISPRS TC V Mid-term Symposium "Geospatial Technology - Pixel to People", 20-23 November 2018, Dehradun, India

\begin{tabular}{|c|c|c|c|}
\hline $\begin{array}{l}\text { House Blocks: } \\
\text { C5-C } 8(8 \mathrm{P})\end{array}$ & 32 & 175 & 4.47 \\
\hline $\begin{array}{c}\text { House Blocks: } \\
\text { E3-E4 }\end{array}$ & 14 & 200 & 2.24 \\
\hline $\begin{array}{l}\text { House Blocks: } \\
\text { E2 }\end{array}$ & 10 & 200 & 1.60 \\
\hline $\begin{array}{c}\text { SECURITY } \\
\text { OFFICE } \\
\end{array}$ & 7 & 45 & 0.25 \\
\hline $\begin{array}{c}\text { House Blocks: } \\
\text { E1 }\end{array}$ & 10 & 200 & 1.60 \\
\hline LIBRARY & 50 & 45 & 1.80 \\
\hline CANTEEN & 300 & 70 & 16.77 \\
\hline BLOCK C & 30 & 135 & 3.23 \\
\hline $\begin{array}{c}\text { NEW ADMIN } \\
\& \\
\text { AUDITORIUM }\end{array}$ & 500 & 45 & 19.77 \\
\hline $\begin{array}{c}\text { CSSTEAP } \\
\text { HOSTEL }\end{array}$ & 100 & 135 & 10.78 \\
\hline BLOCK B & 60 & 135 & 6.47 \\
\hline CSSTEAP & 60 & 70 & 3.35 \\
\hline $\begin{array}{c}\text { MAIN } \\
\text { BUILDING }\end{array}$ & 500 & 45 & 17.97 \\
\hline STORE & 10 & 45 & 0.36 \\
\hline GID & 150 & 45 & 5.39 \\
\hline URSD & 300 & 45 & 10.78 \\
\hline NEW MESS & 400 & 70 & 23.97 \\
\hline $\begin{array}{c}\text { NEW HOSTEL } \\
1 \\
\end{array}$ & 120 & 135 & 13.94 \\
\hline $\begin{array}{c}\text { NEW HOSTEL } \\
2 \\
\end{array}$ & 150 & 135 & 17.17 \\
\hline B1 - B6(6P) & 36 & 135 & 3.88 \\
\hline $\begin{array}{l}\text { GOLDEN } \\
\text { JUBILEE } \\
\end{array}$ & 300 & 135 & 28.2 \\
\hline $\begin{array}{l}\text { GUEST } \\
\text { HOUSE }\end{array}$ & 50 & 135 & 5.39 \\
\hline DISPENSARY & 10 & 45 & 0.36 \\
\hline FOUNTAIN & & & 0.70 \\
\hline \multirow[t]{4}{*}{ Iirs Colony 1} & 126 & 200 & \\
\hline & 40 & 135 & \\
\hline & 16 & 135 & \\
\hline & & Total & 27.25 \\
\hline Iirs Colony 2 & 28 & 200 & 5.47 \\
\hline \multirow[t]{2}{*}{$\begin{array}{l}\text { Gym \& } \\
\text { Parking } \\
\end{array}$} & 100 & 75 & 5.99 \\
\hline & & & $\begin{array}{c}346.87 \\
\text { lpm }\end{array}$ \\
\hline
\end{tabular}

Table 9 Future Demand Chart

Demand is calculated according to Indian Standard Code 1172 : 1993 Code of Basic Requirements for Water Supply, Drainage and Sanitation (Institution[ISI], 1984). 